\title{
Technological characteristics of reject waters from aerobic sludge stabilization in small and medium-sized wastewater treatment plants with biological nutrient removal
}

\author{
Zbigniew Mucha $^{1}$ (D) . Jerzy Mikosz ${ }^{1}$ (D)
}

Received: 26 June 2020 / Accepted: 5 September 2020 / Published online: 17 September 2020

(c) The Author(s) 2020

\begin{abstract}
Most studies on the impact of reject waters recycled from sludge processing in the multi-phase activated sludge process focus on anaerobic sludge treatment in large wastewater treatment plants, leaving apart the processes of aerobic sludge stabilization often used in smaller facilities in rural and suburban areas. The article presents the results of tests carried out in three small and medium-sized wastewater treatment plants with biological removal of biogenic compounds that use aerobic stabilization to process sludge. The research concerned the quantity and quality of reject waters generated in the process of aerobic stabilization and dewatering of sewage sludge and their impact on the multi-phase activated sludge process. The results showed that the average volume of generated reject waters ranged from 3.2 to $5 \%$ of the incoming wastewater volume. The average share of organic compounds and total nitrogen loads contained in reject waters did not usually exceed 5-10\% of the loads in raw wastewater but reached almost $50 \%$ in the case of total phosphorus. Studies indicated that the composition of the supernatant from aerobic stabilization is strongly dependent on the course of the process. The best quality was obtained for cyclic operation of the aerobic stabilization tank with $16 \mathrm{~h}$ of aeration and $8 \mathrm{~h}$ of settling. The results also showed the negative impact of sudden discharges of reject waters from sludge processing to a multi-phase biological reactor, which can be reduced by using an appropriate equalization tank and pretreatment of the side stream to reduce the recirculation of phosphorus.
\end{abstract}

Keywords Small wastewater treatment plant · Biological nutrient removal · Aerobic stabilization · Sludge processing · Reject water

\section{Introduction}

Sludge treatment should ensure the elimination of odour nuisance (stabilization) and a reduction of sludge volume (thickening and dewatering) [1]. These processes lead to the generation of large volumes of reject waters. In the past, the problem of the impact of reject waters on biological treatment processes concerned rather large wastewater treatment plants (WWTPs) in which anaerobic digestion was used to stabilize the sludge [2-4]. However, the European Union's requirements for the quality of treated wastewater imposed

Jerzy Mikosz

jmikosz@pk.edu.pl

1 Division of Environmental Technologies, Faculty of Environmental and Power Engineering, Cracow University of Technology, ul. Warszawska 24, 31-155 Cracow, Poland on agglomerations with a population equivalent (PE) above 10,000 , resulting from the implementation of Directive 91/271/EEC concerning urban wastewater treatment, also make it necessary to remove nitrogen and phosphorus in small and medium-sized WWTPs located in such agglomerations [5]. This is usually done by means of advanced multiphase activated sludge reactors. The use of highly effective biological methods for nutrient removal (BNR) causes the formation of a large amount of sewage sludge requiring treatment and disposal. For this reason, the problem of reject waters has also begun to affect small and mediumsized WWTPs, where stabilization usually takes place under aerobic conditions in dedicated stabilization tanks [6].

The dewatering process is sometimes preceded by gravity thickening of the sludge in the aerobic stabilization tank with removal of the supernatant in order to reduce its volume before dewatering. The reject waters generated during these processes are usually recycled to the wastewater treatment 
train. In large WWTPs, reject water is often subjected to pretreatment using processes based on Anammox bacteria, chemical phosphate precipitation, ion exchange, or membrane filtration. In smaller facilities, these waters usually do not undergo any prior treatment and thus contribute to an increased loading on the biological part of the plant. Large amounts of highly concentrated reject waters appearing periodically in the inflow can noticeable disturb the biological processes in small and medium-sized WWTPs.

Limited information is available in the literature on the characteristics and impact of reject waters from aerobic sludge processing in small and medium-sized WWTPs. Most research is focused on large WWTPs with anaerobic digestion of sewage sludge. Reviews of such research are presented in, for example, [7-10]. The volume and composition of reject waters vary and are highly dependent on the technology used to treat the sludge and the process conditions. Based on data from Germany, the volume of reject water is estimated as $2-5 \%$ of the volume of treated wastewater and the loads of nitrogen and phosphorus as 10-30\% and 2-5\%, respectively [11]. In a review article, Solon cites similar values for the amount of reject water $(2 \%)$ and the share of nitrogen load (10-30\%) but much higher values for phosphorus (10-80\%) [8]. Ryzińska [2], on the basis of data from several dozen large WWTPs, reports that the volume of reject water is most often several percent and usually does not exceed $7 \%$ of the volume of treated wastewater, while the ammonium nitrogen load can reach $50 \%$ of the influent load.

The composition of reject waters is very diverse and depends on the type of sludge treatment process and its parameters. Based on a comprehensive data set from Germany, the concentration of organic pollutants in reject waters from the aerobic stabilization process of sludge after gravity thickening was in the range of $500-1500 \mathrm{~g} / \mathrm{m}^{3}$ for the fiveday biochemical oxygen demand $\left(\mathrm{BOD}_{5}\right)$ and $1000-3000 \mathrm{~g} /$ $\mathrm{m}^{3}$ for chemical oxygen demand (COD) [11]. For the same sludge, $\mathrm{BOD}_{5}$ in process water from mechanical sludge dewatering was in the range of $800-3000 \mathrm{~g} / \mathrm{m}^{3}$, while COD was between 1000 and $6000 \mathrm{~g} / \mathrm{m}^{3}$. The high variability of the quality of reject water from dewatering of aerobically stabilized sludge is also indicated in the Water Environment Federation Manual [12]. The reported average concentration of total Kjeldahl nitrogen (TKN) was $170 \mathrm{~g} \mathrm{~N} / \mathrm{m}^{3}$ (values varied from 10 to 400) and that of total phosphorus (TP) was $100 \mathrm{~g} \mathrm{P} / \mathrm{m}^{3}$ (values varied from 19 to 241). For a system with excess biological phosphorus removal (EBPR), Lu-Kwang et al. [13] provide values of phosphorus concentration in reject waters in the range of $60-130 \mathrm{~g} \mathrm{P} / \mathrm{m}^{3}$. According to the characteristics of reject waters presented by Dąbrowski, based on tests carried out in four municipal WWTPs with aerobic sludge stabilization in Poland, BOD $_{5}$ was between 142 and $400 \mathrm{~g} / \mathrm{m}^{3}$ and COD between 210 and $860 \mathrm{~g} / \mathrm{m}^{3}[14,15]$. In the same studies, TKN concentration was found to be in the range of $8.7-150 \mathrm{~g} \mathrm{~N} / \mathrm{m}^{3}$, ammonia $\left(\mathrm{NH}_{3}\right)$ in the range of $12.6-114.1 \mathrm{~g} \mathrm{~N}-\mathrm{NH}_{3} / \mathrm{m}^{3}$, and TP in the range of 1.14-24.5 g P/m $\mathrm{m}^{3}$. In their laboratory tests, Bin Ji et al. [16] observed that with increasing time of aerobic stabilization, the total nitrogen (TN) concentration in the supernatant grew from 8 to $17 \mathrm{~g} \mathrm{~N} / \mathrm{m}^{3}$ and TP grew from 0.4 to $1.5 \mathrm{~g} \mathrm{P} / \mathrm{m}^{3}$. Also, the reject water from thermophilic aerobic stabilization is characterized by a high concentration of nitrogen and phosphorus. Dąbrowski [17] estimates these values at around $1487( \pm 166) \mathrm{g} \mathrm{N} / \mathrm{m}^{3}$ for TKN and 128.5 $( \pm 16.7) \mathrm{g} \mathrm{P} / \mathrm{m}^{3}$ for TP.

Data from facilities using aerobic stabilization also indicate the negative impact of nitrogen and phosphorus compounds recirculated with reject waters on BNR processes in activated sludge reactors. For example, in research carried out in a WWTP in Florida, Kassouf et al. [18] found that about half of the TP load treated in a biological reactor comes from processing of aerobically stabilized sludge, which significantly increases the plant's operating costs. In the case of nitrogen, it accounts for only about $3 \%$ of the load in raw wastewater, but nitrogen occurs mainly in the form of nitrates, which in turn can disrupt the EBPR process, also contributing to an increase in operating costs.

\section{Materials and methods}

\section{Description of the facilities}

The three tested WWTPs receive biologically degradable wastewater comprising domestic effluents with a small share of industrial wastewater. The pollution loads in the investigated WWTPs exceed $80 \%$ of the design values. The analysed facilities have to remove $\mathrm{N}$ and $\mathrm{P}$ from wastewater due to their location in established agglomerations of PE $>10,000$ and the use of dedicated aerobic stabilization for sludge processing.

Two facilities apply a flow-through multiphase activated sludge BNR process (WWTPs \#1 and \#2) and WWTP \#3 applies a cyclic system with sequencing batch reactors (SBRs). The illustrative photos of both types of the tested WWTPs are shown in Fig. 1. All these WWTPs periodically use supplementary chemical phosphorus precipitation with ferrous sulfate. In each WWTP, biological treatment is preceded by mechanical pretreatment using fine sieves and grit tanks. In addition, in WWTP \#2, the mechanically treated wastewater flow is equalized in the retention tank, to which the process water from the centrifuge is also directed. The sludge produced in the plants is subjected to aerobic stabilization in dedicated aeration tanks, where it is also gravity thickened with removal of the supernatant in order to reduce its volume. The sludge is then dewatered with centrifuges (WWTP \#1 and \#2) or a filter press (WWTP \#3). The reject 
Fig. 1 Illustrative photos of the plants under study: a plant with flow-through reactor (WWTP \#2); b plant with cyclic reactor (WWTP \#3); (1) covered flowthrough biological reactor, (2) open-air SBR

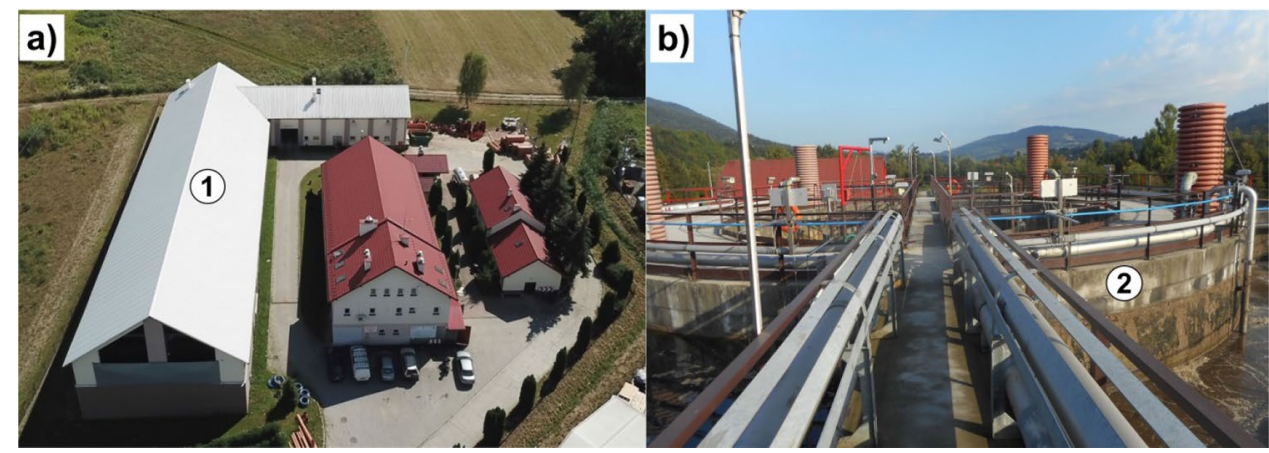

WWTPs are presented in Fig. 2. Table 1 presents the main

waters generated during these processes are recycled to the wastewater treatment train. The flow schemes of the tested

WWTP \#1

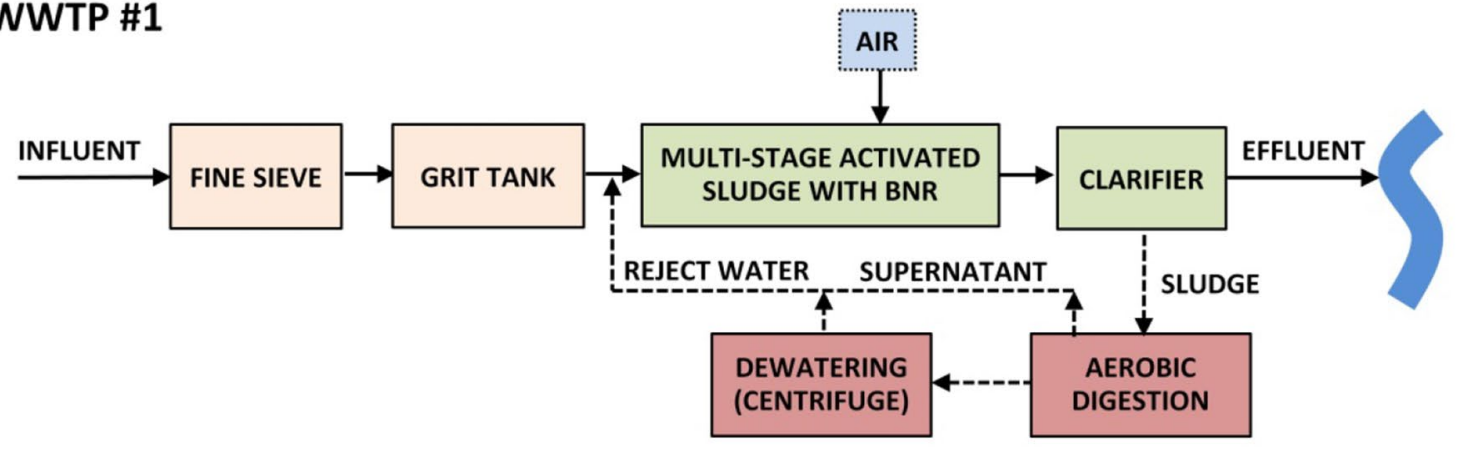

WWTP \#2
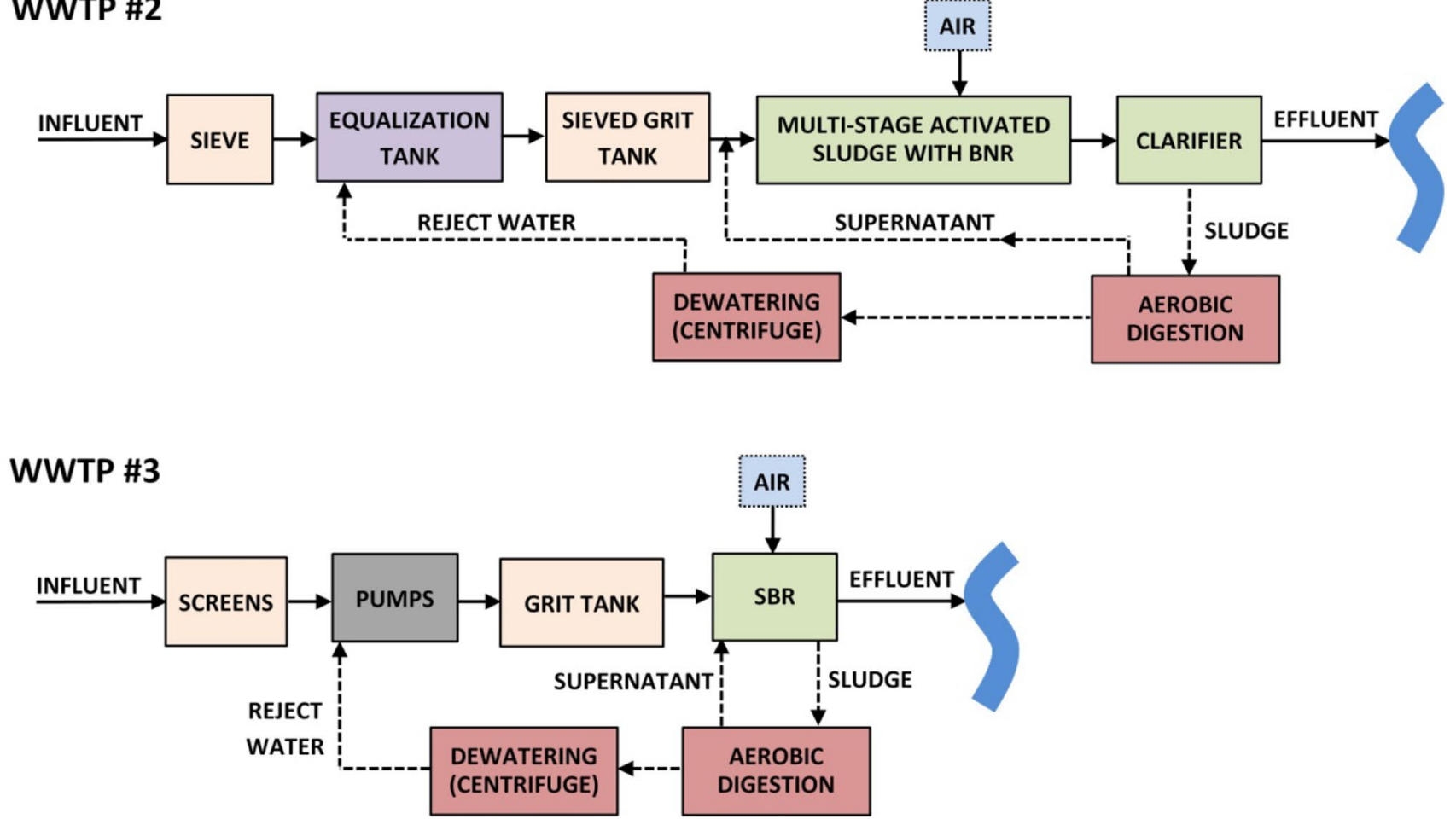

Fig. 2 Technological flow schemes of the tested wastewater treatment plants 
Table 1 Summary of the main operational parameters of the tested WWTPs

\begin{tabular}{llll}
\hline Parameter & WWTP \#1 & WWTP \#2 & WWTP \#3 \\
\hline Wastewater flow $\left(\mathrm{m}^{3} / \mathrm{d}\right)$ & 900 & 1500 & 2650 \\
PE & 5350 & 12,900 & 16,550 \\
Solids retention time (SRT), days & $10-12$ & $15-16$ & 13 \\
Sludge mass per year, tDS & 108 & 263 & 340 \\
Dewatered sludge DS content $(\%)$ & 24.4 (centrifuge) & 21.3 (centrifuge) & 13.0 (press) \\
Daily volume of supernatant $\left(\mathrm{m}^{3}\right)$ & 22.8 & 29.0 & 21.5 \\
Daily volume of process water $\left(\mathrm{m}^{3}\right)$ & $13(0-91)$ & 44 & 64 \\
\hline
\end{tabular}

${ }^{\mathrm{a}}$ Tonne $(\mathrm{Mg})$ of dry solids (DS)

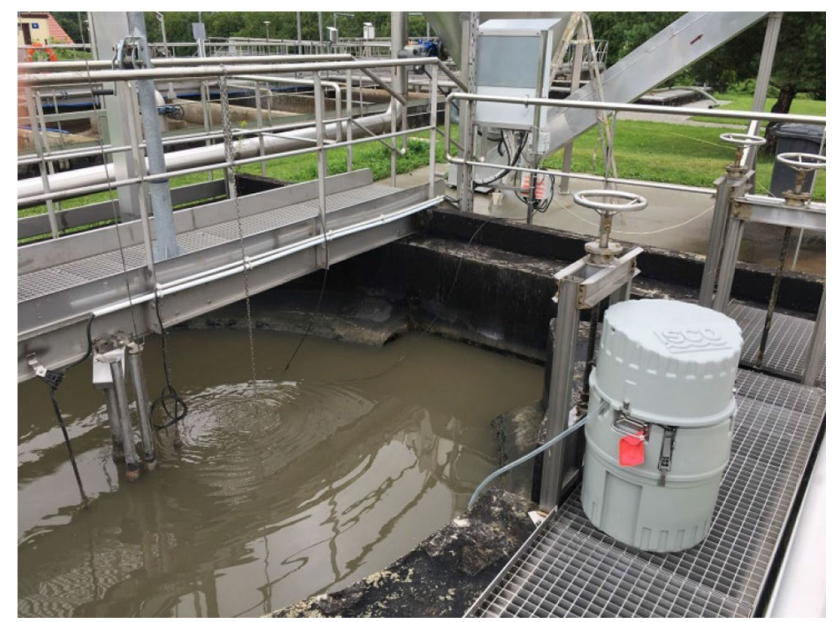

Fig. 3 Sampling of mechanically treated wastewater mixed with reject waters in WWTP \#1

technological parameters of the plants in regard to their capacities and sludge processing.

\section{Sampling}

The tests were carried out from May to November 2018 during the normal operation of the WWTPs. During the research, the quantity and quality of wastewater and sludge, as well as the supernatant from stabilization tanks and the leachate from sludge dewatering devices, were monitored. Excess sludge, sludge from stabilization tanks, and dewatered sludge were also analysed. Samples of raw and treated wastewater for physical and chemical analyses were collected using portable sampling devices, and samples of reject water and sludge were collected manually and averaged over the sampling time (Fig. 3). Analytical tests of the samples were carried out in the laboratory of Cracow University of Technology or in the laboratories of the WWTPs in accordance with standard methods [19]. During transport, the samples were appropriately cooled to $4{ }^{\circ} \mathrm{C}$ and preserved.
Various modes of operation of the sludge stabilization tank with continuous and cyclic aeration were tested in WWTP \#2. During cyclic operation, the sludge was aerated for about $16 \mathrm{~h}$ and then left without aeration for several hours. Excess sludge was supplied to the tank during both phases of its operation. The amount of data obtained from WWTP \#2 (25 to 40 samples for different sampling points) allowed their statistical analysis. For the other plants (WWTP, \#1 and \#2), the range and average values of pollution indicators are presented. Data obtained from each WWTP are presented in Tables 2, 3 .

\section{Results}

\section{Volumes of reject waters}

Process waters in the analysed facilities are generated irregularly, which results from the operational schedule of sludge dewatering devices. In WWTP \#1, sludge dewatering usually takes place once a week, and during $10 \mathrm{~h}$ of the centrifuge operation process $91 \mathrm{~m}^{3}$ of water flows into the biological reactor. Every day, $22.8 \mathrm{~m}^{3}$ of the supernatant is also discharged from the aerobic stabilization tank for $2 \mathrm{~h}$. In total, during the $12 \mathrm{~h}$ of the sludge dewatering cycle, about $113.8 \mathrm{~m}^{3}$ of reject water flows into the biological reactor, which is about $12.6 \%$ of the volume of the daily wastewater flow to the plant. In the remaining period of the plant's operation, the amount of reject water accounts for $2.5 \%$ of the wastewater flow. The average amounts of reject waters in other treatment plants ranged from 3.2\% (WWTP \#3 with belt press) to 5\% (WWTP \#2 with centrifuge) and are comparable with the literature data (e.g. [4, 11, 14].).

\section{Quality of reject waters}

The composition of the reject water is very diverse and depends on the sludge treatment processes, mainly the stabilization process. The results show that in the process water from the centrifuge and in the supernatant from the stabilization tanks, after periods without aeration in the sludge 
Table 2 Quality of the supernatant from aerobic stabilization in the tested plants
Table 3 Quality of the process water from sludge dewatering in the tested plant

\begin{tabular}{|c|c|c|c|}
\hline Parameter & WWTP \#1 & WWTP \#2 $2^{\mathrm{a}}$ & WWTP\#3 \\
\hline $\mathrm{BOD}_{5}\left(\mathrm{~g} / \mathrm{m}^{3}\right)$ & $221.5(107-407)$ & $290(133-513)$ & $155.3(27-245)$ \\
\hline $\operatorname{COD}\left(\mathrm{g} / \mathrm{m}^{3}\right)$ & 746.7 (318-1667) & $624.8(137-1122)$ & $390.3(153-614)$ \\
\hline Filtered COD $\left(\mathrm{g} / \mathrm{m}^{3}\right)$ & $266.3(134-482)$ & - & - \\
\hline $\operatorname{TSS}\left(\mathrm{g} / \mathrm{m}^{3}\right)$ & $653.5(268-1456)$ & - & $82.2(56-131)$ \\
\hline $\operatorname{VSS}\left(\mathrm{g} / \mathrm{m}^{3}\right)$ & 312.5 (68-932) & - & - \\
\hline $\mathrm{TN}\left(\mathrm{g} \mathrm{N} / \mathrm{m}^{3}\right)$ & $133.0(121-190)$ & $115(55-200)$ & $66.5(32-95)$ \\
\hline Ammonia $\left(\mathrm{g} \mathrm{N}-\mathrm{NH}_{3} / \mathrm{m}^{3}\right)$ & $90.0(23.5-172)$ & $86.9(41-179)$ & $46.3(17-68)$ \\
\hline 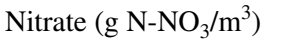 & $0.50(0.24-1.20)$ & $0.60(0.09-1.06)$ & - \\
\hline $\mathrm{TP}\left(\mathrm{g} \mathrm{P} / \mathrm{m}^{3}\right)$ & $159.3(106-331)$ & $137.4(119-165)$ & $57.5(10-82)$ \\
\hline Phosphate $\left(\mathrm{g} \mathrm{P}^{-\mathrm{PO}_{4}} / \mathrm{m}^{3}\right)$ & $70.8(61-105)$ & $127.6(114-145)$ & $53.5(7-77)$ \\
\hline $\mathrm{pH}$ & $6.99-7.31$ & $6.80-6.90$ & $6.89-7.10$ \\
\hline
\end{tabular}

${ }^{\mathrm{a}}$ Under irregular aeration in the stabilization tank

\begin{tabular}{|c|c|c|c|}
\hline Parameter & WWTP \#1 & WWTP \#2 ${ }^{\mathrm{a}}$ & WWTP\#3 \\
\hline Dewatering method & centrifuge & centrifuge & belt press \\
\hline $\mathrm{BOD}_{5}\left(\mathrm{~g} / \mathrm{m}^{3}\right)$ & $112(63-140)$ & - & $188.7(14-311)$ \\
\hline $\operatorname{COD}\left(\mathrm{g} / \mathrm{m}^{3}\right)$ & $495(430-589)$ & 849.7 (183-1542) & $424.5(118-749)$ \\
\hline Filtered COD $\left(\mathrm{g} / \mathrm{m}^{3}\right)$ & $287(202-320)$ & - & - \\
\hline $\operatorname{TSS}\left(\mathrm{g} / \mathrm{m}^{3}\right)$ & $291(128-476)$ & - & $125.4(68-170)$ \\
\hline $\operatorname{VSS}\left(\mathrm{g} / \mathrm{m}^{3}\right)$ & $90(24-178)$ & - & - \\
\hline $\mathrm{TN}\left(\mathrm{g} \mathrm{N} / \mathrm{m}^{3}\right)$ & $151.6(101-184)$ & $133.9(85-199)$ & $73.8(36-101)$ \\
\hline Ammonia $\left(\mathrm{g} \mathrm{N}-\mathrm{NH}_{3} / \mathrm{m}^{3}\right)$ & $135.5(74-152)$ & $89.1(62-130)$ & $53.3(22-68)$ \\
\hline Nitrate $\left(\mathrm{g} \mathrm{N}-\mathrm{NO}_{3} / \mathrm{m}^{3}\right)$ & $0.40(0.21-0.45)$ & $0.80(0.07-2.27)$ & - \\
\hline $\mathrm{TP}\left(\mathrm{g} \mathrm{P} / \mathrm{m}^{3}\right)$ & $106.9(65-118)$ & $154.4(121-177)$ & $57.0(11-77)$ \\
\hline Phosphate $\left(\mathrm{g} \mathrm{P}-\mathrm{PO}_{4} / \mathrm{m}^{3}\right)$ & $76.1(57-95)$ & $135.9(115-157)$ & $54.4(9-71)$ \\
\hline $\mathrm{pH}$ & $6.73-7.55$ & $7.10-7.30$ & $6.69-6.97$ \\
\hline
\end{tabular}

${ }^{\mathrm{a}}$ Under irregular aeration in the stabilization tank stabilization tank (irregular aeration), high ammonium concentrations comparable to those in typical raw municipal wastewater appear, as well as very high phosphate concentrations, as much as ten times higher than in raw wastewater (Tables 2, 3). In the event of improper operation of the stabilization tank, high contents of total suspended solids (TSS) and volatile suspended solids (VSS) are also detected in the supernatant in WWTP \#1 (Table 2).

As shown in Fig. 4a-c, pollution loads in process waters from the press or centrifuge presented in comparison with the pollution loads in the supernatant discharged from the aerobic stabilization tanks are clearly higher for WWTPs \#2 and \#3. A different situation occurred in WWTP \#1. Due to the careless operation of the stabilization tank and the discharge of a significant amount of suspended solids, the load of pollutants in the supernatant for some indicators was more than twice as high as the loads of pollutants in the process water. The average share of organic pollutant loads $\left(\mathrm{BOD}_{5}\right.$ and COD), TSS, and nitrogen in reject waters from aerobic stabilization of sludge introduced into the wastewater treatment stream usually does not exceed $10 \%$ of the load in raw wastewater (Fig. 4d). A much higher load was found in reject waters for TP. In the case of irregular discharge of supernatant, the load of pollutants can be much higher.

\section{Effect of aeration mode on the composition of reject water (WWTP \#2)}

The load of pollutants contained in reject waters can be reduced by the proper operation of aerobic stabilization tanks. Such tests were carried out in WWTP \#2 and consisted of changing the method of aeration of aerobic stabilization tanks from irregular to continuous to cyclic. The operation of the stabilization tanks with cyclic aeration consisted in aerating the sludge in the tank for $16 \mathrm{~h}$ and then cutting off the air supply for $8 \mathrm{~h}$. The best results were obtained for the cyclic aeration mode (Table 4). In comparison with the results presented in Fig. 4d for WWTP \#2, the share of pollution loads in reject waters was reduced to $0.6 \%$ for COD, $0.7 \%$ for $\mathrm{TN}$, and $16.3 \%$ for $\mathrm{TP}$. 
Fig. 4 Pollution loads in the supernatant and process water in the tested WWTPs $(\mathbf{a}-\mathbf{c})$ and the share of pollutant loads in reject waters in the influent load for each plant (d)

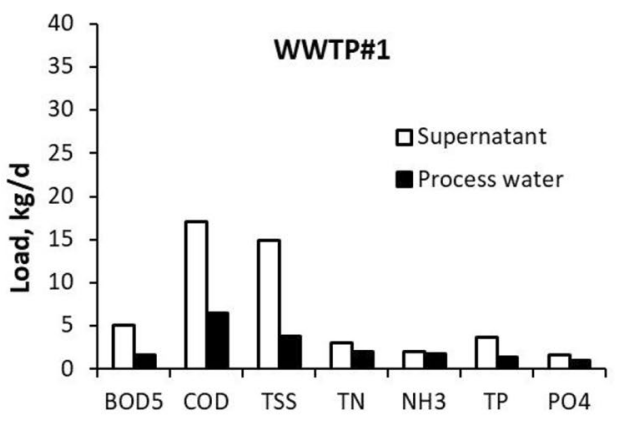

(a)

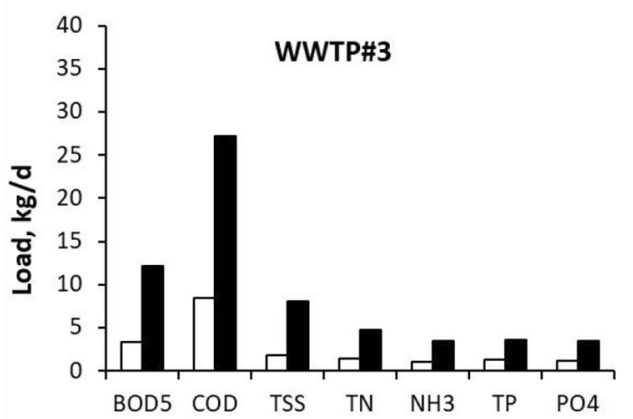

(c)

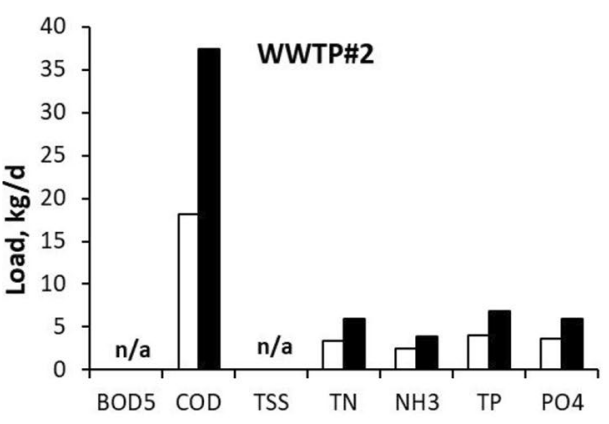

(b)

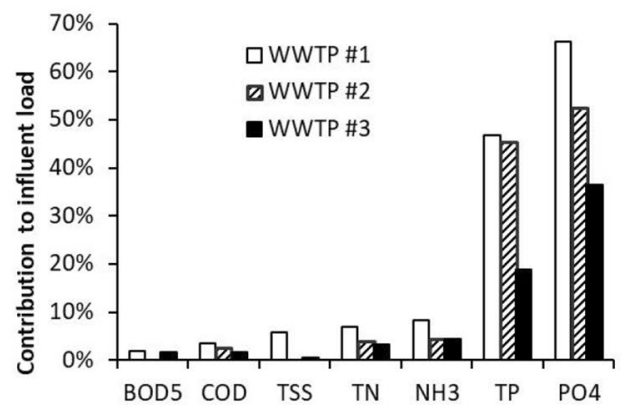

(d)
Table 4 Quality of process water discharged from the centrifuge for various modes of operation of the stabilization tank in WWTP \#2

\begin{tabular}{|c|c|c|c|}
\hline \multirow[t]{2}{*}{ Parameter } & \multicolumn{3}{|c|}{ Operational mode (aeration) } \\
\hline & Irregular & Continuous & Cyclic (16/8 h) \\
\hline $\operatorname{COD}\left(\mathrm{g} / \mathrm{m}^{3}\right)$ & $849.7(183-1542)$ & $242.7(182-296)$ & $203.2(136-311)$ \\
\hline $\mathrm{TN}\left(\mathrm{g} \mathrm{N} / \mathrm{m}^{3}\right)$ & $133.9(85-199)$ & $239.7(188-329)$ & $31.5(12-72)$ \\
\hline Ammonia $\left(\mathrm{g} \mathrm{N}-\mathrm{NH}_{3} / \mathrm{m}^{3}\right)$ & $89.1(62-130)$ & $26.6(0.5-84)$ & $16.3(0.3-53)$ \\
\hline Nitrate $\left(\mathrm{g} \mathrm{N}-\mathrm{NO}_{3} / \mathrm{m}^{3}\right)$ & $0.80(0.07-2.27)$ & $191.4(165-221)$ & $0.97(0.4-3.6)$ \\
\hline $\mathrm{TP}\left(\mathrm{g} \mathrm{P} / \mathrm{m}^{3}\right)$ & $154.4(121-177)$ & - & $47.5(12-136)$ \\
\hline Phosphate $\left(\mathrm{g} \mathrm{P}^{-\mathrm{PO}_{4}} / \mathrm{m}^{3}\right)$ & $135.9(115-157)$ & $78.6(36-106)$ & $43.3(6-120)$ \\
\hline $\mathrm{pH}$ & $7.10-7.30$ & $5.45-6.58$ & $7.10-7.42$ \\
\hline
\end{tabular}

The aeration mode during sludge stabilization also affects the composition of the supernatant discharged from the stabilization tank. The transition from irregular to cyclic aeration (in 16/8 $\mathrm{h}$ mode) drastically reduced the concentrations of organic pollutants as well as nitrogen and phosphorus in supernatant. COD was reduced from 625 to $125 \mathrm{~g} / \mathrm{m}^{3}$, TN from 115 to $6.9 \mathrm{~g} \mathrm{~N} / \mathrm{m}^{3}$, ammonia from 87 to $1.6 \mathrm{~g} \mathrm{~N}-\mathrm{NH}_{3} /$ $\mathrm{m}^{3}$, and orthophosphates from 127 to $38 \mathrm{~g} \mathrm{P} / \mathrm{m}^{3}$. Nitrate concentration in supernatant remained almost unchanged $\left(0.4\right.$ vs. 0.6 g N-NO${ }_{3} / \mathrm{m}^{3}$ ).

\section{Effect on the effluent quality (WWTP \#2)}

The reject water together with all the pollutants contained in it is usually introduced into the wastewater stream being treated and affects the course of wastewater treatment processes through both the size of the introduced pollutant loads and the way in which they are mixed with treated wastewater. The method of mixing has an impact on the operating parameters of the treatment plant (e.g. energy consumption) and the quality of treated wastewater. The process water can be discharged directly to the wastewater stream flowing into the biological reactor or can be mixed with the wastewater in the equalization tank. The latter option is definitely better. This can be clearly seen from the results of tests performed in WWTP \#2. Table 5 shows the concentrations of pollutant indicators in the average daily samples in the raw wastewater entering WWTP \#2 and after mixing them in the equalizing tank with process water from the centrifuge. In the tank with a detention time of several hours, quantitative and qualitative equalization of the mixture of wastewater and process waters takes place. In the case of organic pollutants $\left(\mathrm{BOD}_{5}\right.$ and COD), TSS, TN, and ammonia, there is clearly no negative impact of the added process waters on the quality of 
Table 5 Comparison of the quality of raw wastewater, effluent from the equalizing tank, and treated wastewater for WWTP \#2

\begin{tabular}{|c|c|c|c|c|c|c|}
\hline \multirow[t]{2}{*}{ Parameter } & \multicolumn{2}{|l|}{ Raw } & \multicolumn{2}{|l|}{ Mixed } & \multicolumn{2}{|l|}{ Effluent } \\
\hline & Range & $\operatorname{Mean} \pm \delta^{\mathrm{a}}$ & Range & $\operatorname{Mean} \pm \delta^{\mathrm{a}}$ & Range & $\operatorname{Mean} \pm \delta^{\mathrm{a}}$ \\
\hline $\mathrm{BOD}_{5}\left(\mathrm{~g} / \mathrm{m}^{3}\right)$ & $282-744$ & $515 \pm 116$ & $330-644$ & $427 \pm 85.7$ & $2-26$ & $5.3 \pm 4.8$ \\
\hline $\operatorname{COD}\left(\mathrm{g} / \mathrm{m}^{3}\right)$ & $742-2300$ & $1444 \pm 468$ & $757-1472$ & $1085 \pm 176$ & $30.2-87.5$ & $43.5 \pm 12.3$ \\
\hline Filtered COD $\left(\mathrm{g} / \mathrm{m}^{3}\right)$ & $317-882$ & $608 \pm 283$ & $206-633$ & $431 \pm 93.4$ & $27.4-62.4$ & $42.3 \pm 10.3$ \\
\hline $\operatorname{TSS}\left(\mathrm{g} / \mathrm{m}^{3}\right)$ & $324-5156$ & $1092 \pm 1259$ & $246-740$ & $464 \pm 109.5$ & $1.2-23$ & $9.4 \pm 5.6$ \\
\hline $\mathrm{TN}\left(\mathrm{g} \mathrm{N} / \mathrm{m}^{3}\right)$ & $122-317$ & $157 \pm 42.5$ & $88.7-191$ & $123 \pm 23.5$ & $7.5-25$ & $11.6 \pm 3.6$ \\
\hline Ammonia $\left(\mathrm{g} \mathrm{N}-\mathrm{NH}_{3} / \mathrm{m}^{3}\right)$ & $69.3-143$ & $95.1 \pm 17.4$ & $57.7-138$ & $79.1 \pm 17.0$ & $0.04-0.80$ & $0.2 \pm 0.2$ \\
\hline Nitrate $\left(\mathrm{g} \mathrm{N}-\mathrm{NO}_{3} / \mathrm{m}^{3}\right)$ & $0.2-4.0$ & $1.8 \pm 1.0$ & $0.05-1.9$ & $1.0 \pm 0.42$ & $2.6-22.1$ & $8.2 \pm 3.3$ \\
\hline Nitrite $\left(\mathrm{g} \mathrm{N}-\mathrm{NO}_{2} / \mathrm{m}^{3}\right)$ & $0.00-0.64$ & $0.32 \pm 0.17$ & $0.00-0.38$ & $0.18 \pm 0.13$ & $0.02-0.75$ & $0.13 \pm 0.12$ \\
\hline $\mathrm{TP}\left(\mathrm{gP} / \mathrm{m}^{3}\right)$ & $10-24$ & $15.8 \pm 4.2$ & $9.6-21$ & $16.4 \pm 3.6$ & $0.2-10.7$ & $2.3 \pm 2.4$ \\
\hline Phosphate $\left(\mathrm{g} \mathrm{P}-\mathrm{PO}_{4} / \mathrm{m}^{3}\right)$ & $9.0-21.6$ & $12.3 \pm 3.7$ & $7.7-20.1$ & $13.1 \pm 3.5$ & $0.08-8.60$ & $1.8 \pm 2.0$ \\
\hline $\mathrm{pH}$ & $7.08-7.75$ & - & $6.93-7.68$ & - & $6.98-7.46$ & - \\
\hline
\end{tabular}

${ }^{\mathrm{a}}$ Standard deviation wastewater. The concentrations in the retention tank are usually lower than in the inflow and their variability is also lower. Only in the case of TP is there a slight increase compared to raw wastewater, which is caused by a very high TP load in the process water from the centrifuge (see Fig. 4d).

\section{Discussion and conclusion}

Small and medium-sized municipal WWTPs with advanced BNR processes usually use aerobic methods to stabilize sewage sludge and mechanical sludge dewatering. The processed sludge is used in agriculture or transported to the incineration plant. Reject waters that are generated during sludge processing carry large loads of pollutants, especially nitrogen and phosphorus, and are periodically discharged into the wastewater treatment line without additional pretreatment. The studies at three WWTPs have shown that TP can account for almost half of the total load entering the biological reactor (Fig. 4d). These results are consistent with data reported by Kassouf et al. [18]. This is due to the high concentration of phosphorus, reaching up to an average of $159 \mathrm{~g} \mathrm{P} / \mathrm{m}^{3}$, both in the supernatant discharged from the aerobic stabilization tank and in process waters from mechanical sludge dewatering. In the samples of supernatant from WWTP \#1, the instantaneous TP concentration reached as high as $331 \mathrm{~g} \mathrm{P} / \mathrm{m}^{3}$. This indicates the need to consider the use of chemical phosphorus precipitation or other methods of pretreatment of reject waters. The shares of other pollutant indicators, such as $\mathrm{BOD}_{5}, \mathrm{COD}$, and TSS, in the total pollutant loads entering the biological reactor usually did not exceed $10 \%$. In the case of TN, these values ranged from $3 \%$ for WWTP \#3 through 4\% for WWTP \#2 to $8 \%$ for WWTP \#1, which confirms the observations of Kassouf et al. [18] indicating a value of about $3 \%$.
The variability of the composition of reject waters results more from the variability of the composition of the supernatant discharged from the aerobic stabilization tank than from process waters from mechanical dewatering. The composition of the latter is relatively constant (Tables 2, 3). In turn, the composition of the supernatant from stabilization tanks largely depends on how the aerobic stabilization process is carried out. During tests, the composition of these waters was observed during three different modes of operation of the tank, differing in the method of aeration: irregular, continuous, or periodic. In each of these cases, the composition of the supernatant was significantly different (Table 4). Apparently, the best quality of the supernatant in relation to all analysed pollution indicators was observed with cyclical operation of the tank in the system of $8 \mathrm{~h}$ of aeration and $16 \mathrm{~h}$ of settling. In other modes of operation, very high concentrations of TN (continuous mode) or organic compounds (irregular mode) were observed. This indicates the possibility of a relatively simple reduction of pollutant loads in the supernatant discharged from the aerobic stabilization tanks through operational optimization of its work cycle using, for example, dynamic computer simulation.

The results of the tests also showed that even if the pollution loads fed by reject waters do not significantly increase the average concentrations of pollutants in the wastewater directed to biological treatment, a brief increase of the activated sludge loading with organic compounds, nitrogen, and phosphorus can have a noticeable negative impact on the BNR processes occurring in the biological reactor. This can be prevented by using an equalizing tank before the biological part of the treatment plant, in which mechanically treated wastewater is mixed with periodically discharged reject waters, and therefore the variability of its composition is compensated. The use of such a tank in WWTP \#2 clearly stabilized fluctuations in the quality of influent fed to the reactor. The mixture of mechanically treated wastewater 
and periodically supplied reject waters flowing out of the equalization tank was characterized by lower average values of pollutant concentration (except for TP) and significantly lower standard deviation values for all pollutant indicators, indicating a well-equalized wastewater composition.

\section{Availability of data and material (data transparency)}

The datasets generated during and/or analysed during the current study are available from the corresponding author on reasonable request.

Funding This study was funded by Politechnika Krakowska (Grant number Ś-3/401/2018/DS).

\section{Compliance with ethical standards}

Conflict of interest The authors declare that they have no conflict of interest.

Open Access This article is licensed under a Creative Commons Attribution 4.0 International License, which permits use, sharing, adaptation, distribution and reproduction in any medium or format, as long as you give appropriate credit to the original author(s) and the source, provide a link to the Creative Commons licence, and indicate if changes were made. The images or other third party material in this article are included in the article's Creative Commons licence, unless indicated otherwise in a credit line to the material. If material is not included in the article's Creative Commons licence and your intended use is not permitted by statutory regulation or exceeds the permitted use, you will need to obtain permission directly from the copyright holder. To view a copy of this licence, visit http://creativecommons.org/licenses/by/4.0/.

\section{References}

1. Mucha, Z., Generowicz, A., Wójcik, W., Jóźwiakowski, K., Baran, S.: Application of multi-criterial analysis to evaluate the method of utilization of sludge from small wastewater treatment plants with sustainable development of rural areas. Environ. Prot. Eng. 42, 97-105 (2016)

2. Ryzińska, J.: Problem wód osadowych i możliwości ich oczyszczania w Polsce [The problem of sludge waters and the possibility of their treatment in Poland]. Gaz. Woda. Tech. Sanit. 7-8, 58-62 (2006)

3. Gajewska, M., Obarska-Pempkowiak, H.: Effect of recycling of reject waters from dewatering the sludges on the operation efficiency of a wastewater treatment plant (in Polish). Przem. Chem. 87, 448-452 (2008)

4. Styka, W., Beńko, P.: Wpływ gospodarowania wodami osadowymi na usuwanie azotu ze ścieków miejskich [Impact of sludge water management on nitrogen removal from urban wastewater]. Gaz. Woda. Tech. Sanit. 9, 16-20 (2007)

5. European Commission: Council Directive 91/271/EEC of 21 May 1991 concerning urban waste-water treatment. EUR-Lex
- 31991L0271 - https://eur-lex.europa.eu/legal-content/EN/ TXT/?uri=CELEX\%3A31991L0271. Accessed 23 November 2019

6. Mikosz, J., Mucha, Z.: Validation of design assumptions for small wastewater treatment plant modernization in line with new interpretation of legal requirements. Ochr. Srodowiska 36, 45-49 (2014)

7. Jardin, N., Thöle, D., Wett, B.: Treatment of sludge return liquors: Experiences from the operation of full-scale plants. In: Proceedings of WEFTEC 2006, Dallas, 21-25 October, 5237-5255 (2006)

8. Solon, K.: Reject water treatment models-literature review. Technical report, Division of Industrial Electrical Engineering and Automation, Lund University, Lund (2015)

9. Karwowska, B., Sperczyńska, E., Wiśniowska, E.: Characteristics of reject waters and condensates generated during drying of sewage sludge from selected wastewater treatment plants. Desalin. Water Treat. (2016). https://doi.org/10.1080/19443 994.2014.989633

10. Gustavsson, D.J.I., Syd, V.A., Malmö, S.: Biological sludge liquor treatment at municipal wastewater treatment plants-a review. Vatten 66, 179-192 (2010)

11. Kollbach, J.S., Gromping, M.: Stickstoffruckbelastung: Stand der Technik 1996/97. Zukunftige Entwicklungen. Enviro Consult GmbH, Neuruppin, TK Verlag Karl Thome-Kozmiensky, ISBN 3-924511-85-3 (1996).

12. WEF: Operation of Municipal Wastewater Treatment Plants. Water Environment Federation Manual of Practice No. 11. 6th ed., vol. III. Alexandria (2007)

13. Ju, L.-K., Shah, H.K., Porteous, J.: Phosphorus release in aerobic sludge digestion. Water Environ. Res. 77, 553-559 (2005)

14. Dąbrowski, W.: Charakterystyka odcieków z tlenowej przeróbki osadów komunalnych i przemysłowych oczyszczalniach województwa podlaskiego [Characteristics of reject water from aerobic digestion in municipal and industrial WWTPs of Podlaskie province]. Inz. Ochr. Srodowiska 13, 43-51 (2010)

15. Dąbrowski, W.: A study of the digestion process of sewage sludge from a dairy wastewater treatment plant to determine the composition and load of reject water. Water Pract. Technol. (2014). https ://doi.org/10.2166/wpt.2014.008

16. Ji, B., Yang, K., Chen, W., Wang, J., Zhu, L.: Impacts of dissolved oxygen and initial sludge concentrations on aerobic stabilization of sewage sludge. Pol. J. Environ. Stud. (2016). https:// doi.org/10.15244/pjoes/59564

17. Malinowski, P., Dąbrowski, W., Karolinczak, B.: Application of SS-VF bed for the treatment of high concentrated reject water from autothermal thermophilic aerobic sewage sludge digestion. J. Ecol. Eng. (2018). https://doi.org/10.12911/22998993/89663

18. Kassouf, H., Parra, A.G., Mulford, L., Iranipour, G., Ergas, S.J., Cunningham, J.A.: Mass fluxes of nitrogen and phosphorus through water reclamation facilities: Case study of biological nutrient removal, aerobic sludge digestion, and sidestream recycle. Water Environ. Res. (2019). https://doi.org/10.1002/wer.1239

19. APHA: Standard Methods for the Examination of Water and Wastewater. 21st ed. American Public Health Association, Washington, DC (2005)

Publisher's Note Springer Nature remains neutral with regard to jurisdictional claims in published maps and institutional affiliations. 